\title{
Estimating seasonal variations in cloud droplet number concentration over the boreal forest from satellite observations
}

\author{
R. H. H. Janssen ${ }^{1}$, L. N. Ganzeveld ${ }^{1}$, P. Kabat ${ }^{1}$, M. Kulmala ${ }^{2}$, T. Nieminen ${ }^{2}$, and R. A. Roebeling ${ }^{3}$ \\ ${ }^{1}$ Earth System Science and Climate Change, Wageningen University and Research Centre, Wageningen, The Netherlands \\ ${ }^{2}$ Department of Physics, P.O. Box 64, 00014 University of Helsinki, Finland \\ ${ }^{3}$ Royal Netherlands Meteorological Institute, De Bilt, The Netherlands
}

Received: 25 February 2011 - Published in Atmos. Chem. Phys. Discuss.: 25 March 2011

Revised: 6 July 2011 - Accepted: 22 July 2011 - Published: 2 August 2011

\begin{abstract}
Seasonal variations in cloud droplet number concentration $\left(N_{\mathrm{CD}}\right)$ in low-level stratiform clouds over the boreal forest are estimated from MODIS observations of cloud optical and microphysical properties, using a sub-adiabatic cloud model to interpret vertical profiles of cloud properties. An uncertainty analysis of the cloud model is included to reveal the main sensitivities of the cloud model. We compared the seasonal cycle in $N_{\mathrm{CD}}$, obtained using $9 \mathrm{yr}$ of satellite data, to surface concentrations of potential cloud activating aerosols, measured at the SMEAR II station at Hyytiälä in Finland. The results show that $N_{\mathrm{CD}}$ and cloud condensation nuclei $(\mathrm{CCN})$ concentrations have no clear correlation at seasonal time scale. The fraction of aerosols that actually activate as cloud droplet decreases sharply with increasing aerosol concentrations. Furthermore, information on the stability of the atmosphere shows that low $N_{\mathrm{CD}}$ is linked to stable atmospheric conditions. Combining these findings leads to the conclusion that cloud droplet activation for the studied clouds over the boreal forest is limited by convection. Our results suggest that it is important to take the strength of convection into account when studying the influence of aerosols from the boreal forest on cloud formation, although they do not rule out the possibility that aerosols from the boreal forest affect other types of clouds with a closer coupling to the surface.
\end{abstract}

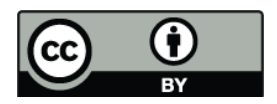

Correspondence to: R. H. H. Janssen (ruud.janssen@wur.nl)

\section{Introduction}

The biosphere makes a very large contribution to the levels of atmospheric aerosols and cloud condensation nuclei (Andreae and Rosenfeld, 2008). However, the feedbacks that are possibly associated with the emissions of natural aerosols have only recently started to receive substantial attention and therefore the scientific understanding of their drivers, climate impacts and interactions is low (Carslaw et al., 2010). One proposed feedback mechanism which involves aerosols of natural origin concerns the boreal forests of the Northern high latitudes. Kulmala et al. (2004) proposed that aerosols produced by forests modify the radiation balance via their influence on cloud properties such as albedo, thereby posing a negative feedback on the surface temperature and on the productivity of the forest itself. They based their hypothesis on the observation that in the boreal forest, there is a strong coupling between the seasonal cycle in temperature, vegetation productivity, biogenic emissions of Volatile Organic Compounds (VOC) and the growth rate of freshly formed aerosol particles. Ongoing research has further confirmed the role of boreal forests as a contributor to both aerosol number by facilitating new particle formation from gaseous precursors (Kavouras et al., 1998; O’Dowd et al., 2002, 2009; Laaksonen et al., 2008) and their subsequent growth by providing condensable species in the form of VOC oxidation products (Allan et al., 2006; Tunved et al., 2006, 2008; Dal Maso et al., 2008).

Some studies have been undertaken to estimate the effect that the vegetation-aerosol-cloud feedback may have on the surface radiation balance in the boreal forest. Spracklen et

Published by Copernicus Publications on behalf of the European Geosciences Union. 
al. (2008) estimated the radiative forcing of the 1st indirect aerosol effect from biogenic aerosols over the boreal forest to be between -1.8 and $-6.7 \mathrm{~W} \mathrm{~m}^{-2}$ using a chemical transport model that includes parameterizations of nucleation and condensational growth coupled to a simple radiation model. Another study that used a more conceptual approach to estimate the radiative forcing of particle formation over the boreal forest yielded numbers up to $-14 \mathrm{~W} \mathrm{~m}^{-2}$ (Kurtén et al., 2003). This would imply that the aerosol effect may be able to compensate for a hypothesized present-day net warming of the boreal forests through the combined effect of a decrease in surface albedo and enhanced $\mathrm{CO}_{2}$-uptake (Betts, 2000; Bala et al., 2007).

New particle formation events are important contributors to the aerosol particle number over the boreal forest (Kulmala et al., 2001; Dal Maso et al., 2007). The occurrence of particle formation events has a typical annual variation over the Scandinavian boreal forest, with peaks in springtime and autumn and minima in winter and summer (Dal Maso et al., 2007). It has been shown that the aerosols that are produced during these nucleation events grow rapidly to sizes at which they can serve as cloud condensation nuclei (CCN) (Lihavainen et al., 2003) and consequently are able to participate in cloud droplet formation (Kerminen et al., 2005). The growth rates of these newly formed particles are strongly correlated to concentrations of monoterpene oxidation products (Laaksonen et al., 2008; Allan et al., 2006). Monoterpenes are emitted in large quantities by boreal forests, following a strong seasonal pattern, determined by a pronounced seasonal cycle in temperature, light intensity and vegetation productivity (Hakola et al., 2003; Lappalainen et al., 2009). Once oxidized, these organics condense onto freshly nucleated clusters to grow them to sizes larger than $3 \mathrm{~nm}$, which allows them to survive as individual aerosols (O'Dowd et al., 2002; Cavalli et al., 2006), and contribute to their further growth to a diameter of 50 to $100 \mathrm{~nm}$, which allows them to act as CCN (Tunved et al., 2008). The findings of these studies were confirmed by Sihto et al. (2010) who derived, from information on the hygroscopicity of the aerosol at Hyytiälä, that aerosols that have grown to the size of $\mathrm{CCN}$ consist for a large part $(\sim 80 \%)$ of organic material.

The number of aerosols that eventually activate into cloud droplets depends on the aerosol concentration, size distribution and chemical properties and on the updraft velocity, which determines the maximum supersaturation in a cloud parcel (McFiggans et al., 2006; Reutter et al., 2009). Once activated into cloud droplets, aerosols affect the cloud optical and microphysical properties through various Aerosol Indirect Effects (AIE). Twomey (1977) suggested that adding aerosols increases the droplet concentration and decrease the droplet size of clouds with a given liquid water path (LWP), which in turn leads to an increase of the cloud albedo (1st indirect effect). Albrecht (1989) proposed that the changes in cloud microphysics lead to a less efficient formation of precipitation and an increase in cloud lifetime (2nd indirect effect), while Lohmann and Feichter (2005) discussed several semi-direct effects such as cloud warming due to increased absorption of solar radiation by black carbon aerosols.

Satellite remote sensing is a widely used tool for determining the AIE. Retrievals of cloud optical thickness and effective radius are required to determine the sensitivity of cloud radiative properties to changes in aerosol concentration (Nakajima et al., 2001; Platnick and Twomey, 1994). Using either of these variables as indicator of the AIE requires the assumption of a constant LWP, which is generally not the case. A way to circumvent this problem is to estimate the cloud droplet number concentration $\left(N_{\mathrm{CD}}\right)$, since it directly links cloud optical and microphysical properties to the aerosol concentration at cloud base. Several methods have been developed for this purpose, each one requiring different assumptions about the sub-adiabatic character of and the mixing that occurs inside clouds (Bennartz, 2007; Boers et al., 2006; Szczodrak et al., 2001).

The method developed by Boers et al. (2006) (hereinafter referred to as B06), was validated by Roebeling et al. (2008), combining ground-based observations of cloud depth $(h)$ and LWP with calculations of the cloud model using data from the SEVIRI-instrument onboard METEOSAT as input. This showed very good agreement for strictly selected cases over the Netherlands.

Until now, however, there is little observational evidence for the influence of aerosols, which are formed in the boreal forest, on cloud optical and microphysical properties. Most of these measurements are performed at a clean background site in northern Finland, Pallas (Komppula et al., 2005; Kerminen et al., 2005; Lihavainen et al., 2008), which is at the northern border of the boreal forest. Recently, Lihavainen et al. (2010) estimated aerosol-cloud interactions over Pallas, using a combination of ground-based and MODIS data of cloud and aerosol properties. Their focus was how quantification of the aerosol burden affects the measured strength of aerosol-cloud interactions comparing ground-based and satellite measurements.

In our study we combine satellite observations of cloud properties over the SMEAR II measurement station at Hyytiälä in Finland with ground-based observations of aerosol concentrations and meteorological fields from ECMWF-reanalysis (1) to assess the seasonal variability in $N_{\mathrm{CD}}$ of low level liquid water clouds over the boreal forest and (2) to determine the role of surface aerosol concentration and meteorology in explaining this variability.

In Section 2 we first present the applied methodology including a description of the selection of the satellite and surface data, an introduction of the cloud model and a detailed uncertainty analysis. Section 3 shows the results of our analysis, including the observed cloud properties and their relation to aerosol concentrations and meteorology. The paper is concluded by a discussion and conclusions Sect. 4 . 


\section{Data and methods}

We present an analysis of cloud properties as observed by the MODIS-instrument onboard the Terra satellite in combination with ground based measurements of aerosol concentration and meteorological fields obtained from the ECMWFserver. As it is not possible to derive $N_{\mathrm{CD}}$ directly from the reflection spectra of solar radiation by clouds, we apply a model which generalizes the properties of stratiform liquid water clouds to estimate $N_{\mathrm{CD}}$. The advantage of using satellite based measurements is that it allows to monitor the seasonal cycle in cloud optical and microphysical properties over several years, and thus get a statistically robust signal. We calculated median values of the satellite, aerosol and meteorological data, divided over 24 bins. For a period of 182 days, this resulted in a bin size of 7.6 days.

\subsection{Satellite data selection}

We used 9 yr (2000-2008) of MODIS-Terra Level2 (collection 005)-data (Platnick et al., 2003), which comprise pixel level retrievals ( $1 \mathrm{~km}$ resolution) of cloud optical and microphysical properties. We averaged cloud properties over a $2 \times 2^{\circ}$ latitude-longitude box centered over the SMEAR II measurement station, Hyytiälä, Finland (Fig. 1).

Since the cloud model is only valid for single-layered water clouds we selected clouds according to their cloud optical thickness $\tau(3.7<\tau<20)$ and cloud top pressure $p_{\mathrm{ct}}$ ( $p_{\mathrm{ct}}>780 \mathrm{hPa}$, corresponding to a cloud top height lower than about $2.5 \mathrm{~km}$ ) based on the ISCCP (International Satellite Cloud Climatology Project) definition of stratocumulus. We realize that these criteria represent only an approximate climatological relationship between satellite derived cloud properties and the classical morphological cloud types and therefore do not rule out the inclusion of other types of clouds. Therefore, we tested the sensitivity of our results for the $\tau$-criterion by including also clouds that are optically thicker. We constrained the retrievals to days for which the solar zenith angle did not exceed $60^{\circ}$, which roughly limited our retrievals to the months of April to September, coinciding with the boreal forest growing season. Furthermore, we selected only data with a satellite sensor zenith angle smaller than $60^{\circ}$, to avoid the data to be affected by 3-D-radiative effects in the cloud (Várnai and Marshak, 2007). We only included pixels for which MODIS cloud phase qualified as "opaque water clouds" to exclude the possible influence of ice clouds on the retrieval.

The occurrence of drizzle could affect the MODIS retrievals of cloud droplet effective radius $\left(r_{\text {eff }}\right)$, since it causes a bi-modal cloud droplet distribution, consisting of cloud droplets and drizzle. Since the MODIS retrievals assume a single-modal distribution of cloud droplets the retrieved $r_{\text {eff }}$ may be underestimated in such cases (Bennartz et al., 2010). Therefore, we excluded all satellite observations for which a simultaneous observation of precipitation was done at the

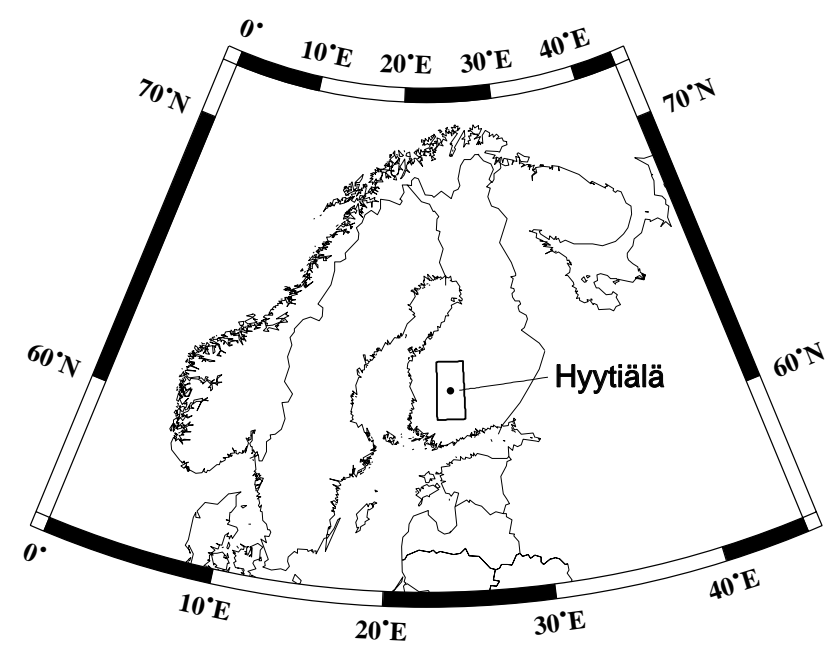

Fig. 1. Map indicating the location of the SMEAR II field station at Hyytiälä, Finland and the $2 \times 2^{\circ}$ latitude-longitude box over which the MODIS and ECMWF-data are averaged.

SMEAR II station. We acknowledge, however, that this does not rule out the possible occurrence of non-ground reaching precipitation.

\subsection{Ground-based measurements}

The observations are performed at the SMEAR II field station at Hyytiälä $\left(61^{\circ} 51^{\prime} \mathrm{N}, 24^{\circ} 17^{\prime} \mathrm{E}\right)$ in southern Finland, where ecosystem, meteorological and aerosol properties are measured since 1996 (Hari and Kulmala, 2005). During the growing season (April-September), the air masses that arrive at the site are mostly of marine origin, except for the months of April when advection of continental air dominates and July when advection of marine and continental air masses have equal shares (Sogacheva et al., 2008). Levels of anthropogenic pollution are low, especially during periods when air masses arrive from the sparsely populated northern sector. For a more detailed site description, see e.g. Kulmala et al. (2001).

Aerosol size distribution data are obtained from a differential mobility particle sizer (DMPS) (Aalto et al., 2001) that measured aerosols in the range from 3 to $500 \mathrm{~nm}$ until December 2004 and aerosols between 3 and $1000 \mathrm{~nm}$ in diameter after that date. The number concentrations of aerosols above a certain activation diameter was obtained by summing the aerosols from that diameter up to the upper limit of the measured size distribution, thus assuming a fixed chemical composition of the aerosol over the size distribution.

Cloud condensation nuclei at various supersaturations have been measured with a CCN counter from July 2008 to June 2009. A more detailed description of these measurements is given by Sihto et al. (2010). 


\subsection{Cloud model}

We used the cloud model of B06 to calculate $N_{\mathrm{CD}}$ and $h$ from satellite observations of cloud droplet effective radius $\left(r_{\mathrm{eff}}\right)$ and cloud optical thickness $(\tau)$.

The model represents the microphysics and thermodynamics of a single-layered water cloud based on functions of the following form:

$N_{\mathrm{CD}}=A_{1} \tau^{1 / 2} r_{\mathrm{eff}}^{-5 / 2}$

and

$h=A_{2} \tau^{1 / 2} r_{\text {eff }}^{1 / 2}$,

where:

$N_{\mathrm{CD}}$ : cloud droplet number concentration $\left(\mathrm{cm}^{-3}\right)$

$h$ : cloud physical thickness (m)

$r_{\text {eff: }}$ effective radius of cloud droplets $(\mu \mathrm{m})$

$\tau$ : cloud optical thickness $(-)$

$A 1, A 2$ : factors that contain the model's uncertainties with respect to cloud thermodynamics and microphysics.

The factors $A 1$ and $A 2$ are not constant, but depend on assumptions about the following four cloud thermodynamic and microphysical factors: (1) the subadiabatic behavior of the cloud, represented by the subadiabatic fraction $F_{\mathrm{r}}$ of the liquid water path, (2) the shape of the liquid water profile (linear or C-shaped), (3) the ratio between the volume radius and effective radius of the cloud droplets $k_{1}$ and (4) if the variation in the vertical profile of the liquid water content (LWC) is associated with variation in the droplet concentration or droplet volume radius or both.

The reason that the model is only valid for stratiform clouds is that these clouds are relatively homogeneous, so that the vertical profiles of LWC, $N_{\mathrm{CD}}$ and other physical cloud properties can be generalized rather easily. The model thus infers low-level, stratiform clouds in or just above the boreal forest boundary layer, the clouds most likely to be affected by the aerosols from the forest.

For the derivation of the model we refer to the papers of B06 and Boers and Rotstayn (2001). Here we limit ourselves to an introduction of the governing equations of the cloud model and focus in particular on the associated uncertainties. The equations to calculate $N_{\mathrm{CD}}$ and $h$ from the input of satellite-based cloud optical properties respectively with the factors $A 1$ and $A 2$ fully written out are:

$$
\begin{aligned}
N_{\mathrm{CD}}= & 2^{-2 / 3} 3^{1 / 2} \pi^{-1}\left(\frac{\rho_{\mathrm{a}}}{\rho_{\mathrm{w}}}\right)^{1 / 2} \\
& A_{\mathrm{ad}}^{1 / 2} k_{1}^{-3} F_{i}^{-1 / 2}\left(F_{\mathrm{r}}, \alpha\right) G_{i}^{5 / 2}\left(F_{\mathrm{r}}, \alpha\right) \tau^{1 / 2} r_{\mathrm{eff}}^{-5 / 2},
\end{aligned}
$$

and

$h=\left[\frac{2}{3}\left(\frac{\rho_{\mathrm{w}}}{\rho_{\mathrm{a}}}\right) A_{\mathrm{ad}}^{-1} F_{i}^{-1}\left(F_{\mathrm{r}}, \alpha\right) G_{i}^{-1}\left(F_{\mathrm{r}}, \alpha\right) \cdot \tau \cdot r_{\mathrm{eff}}\right]^{1 / 2}$ where:

$\rho_{\mathrm{a}}$ : density of air $\left(\mathrm{kg} \mathrm{m}^{-3}\right)$

$\rho_{\mathrm{w}}$ : density of water $\left(\mathrm{kg} \mathrm{m}^{-3}\right)$

$A_{\text {ad }}$ : adiabatic lapse rate of liquid water mixing ratio $\left(\mathrm{g} \mathrm{g}^{-1} \mathrm{~m}^{-1}\right)$

$k_{1}$ : ratio between the second moment of the droplet size (volume radius $r_{\mathrm{v}}$ ) distribution and its 3 rd moment (effective radius $\left.r_{\text {eff }}\right)(-)$

$\alpha$ : factor that determines shape of liquid water vertical profile (-)

$F_{\mathrm{r}}$ : subadiabatic fraction $(-)$

$F_{i}$ and $G_{i}$ are functions related to the mixing model that is used.

It is obvious from these relationships that $N_{\mathrm{CD}}$ and $h$ depend on a large number of parameters which are often poorly constrained. Therefore, a thorough uncertainty analysis is required.

\subsection{Uncertainty analysis}

Calculation of $N_{\mathrm{CD}}$ and $h$ is subject to uncertainties in the retrievals of $r_{\mathrm{eff}}$ and $\tau$ by MODIS and uncertainties that arise from using the cloud model. In this section we discuss possible error sources in both retrieval and the cloud model, whether they are random or systematic and how they propagate through the analysis. We are aware of the fact that the uncertainty estimates are themselves often uncertain, but the following analysis will give some insight in the contributions of the individual input parameters to the total uncertainty estimate.

Since the relation between the input variables and output variables of Eqs. (3) and (4) follows a power law (i.e. $X=Y^{\beta}$ ), the sensitivity of any output variable to any input parameter or variable can be written as:

$\frac{\partial X}{\partial Y}=\beta \frac{X}{Y}$

where:

$\beta$ : exponent of the power law relation between $X$ and $Y$.

If we assume that the errors are normally distributed we can use Gaussian error propagation and write the relative errors of $N_{\mathrm{CD}}$ and $h$, respectively, as follows:

$$
\begin{aligned}
{\left[\frac{\partial N_{\mathrm{CD}}}{N_{\mathrm{CD}}}\right]^{2}=} & {\left[3 \frac{\partial k_{1}}{k_{1}}\right]^{2}+\left[\frac{1}{Z_{1}} \frac{\partial Z_{1}}{\partial F_{\mathrm{r}}}\right]^{2} } \\
& +\left[\frac{1}{2} \frac{\partial A_{\mathrm{ad}}}{A_{\mathrm{ad}}}\right]^{2}+\left[\frac{5}{2} \frac{\partial r_{\mathrm{eff}}}{r_{\mathrm{eff}}}\right]^{2}+\left[\frac{1}{2} \frac{\partial \tau}{\tau}\right]^{2} \\
{\left[\frac{\partial h}{h}\right]^{2}=} & {\left[\frac{1}{Z_{2}} \frac{\partial Z_{2}}{\partial F_{\mathrm{r}}}\right]^{2}+\left[\frac{1}{2} \frac{\partial A_{\mathrm{ad}}}{A_{\mathrm{ad}}}\right]^{2} } \\
& +\left[\frac{1}{2} \frac{\partial r_{\mathrm{eff}}}{r_{\mathrm{eff}}}\right]^{2}+\left[\frac{1}{2} \frac{\partial \tau}{\tau}\right]^{2}
\end{aligned}
$$


where:

$Z_{1}\left(F_{\mathrm{r}}\right)=F^{-\frac{1}{2}}\left(F_{\mathrm{r}}, \alpha\right) G^{\frac{5}{2}}\left(F_{\mathrm{r}}, \alpha\right)$

$Z_{2}\left(F_{\mathrm{r}}\right)=F^{-\frac{1}{2}}\left(F_{\mathrm{r}}, \alpha\right) G^{-\frac{1}{2}}\left(F_{\mathrm{r}}, \alpha\right)$

In the assessment of the uncertainties in the input parameters and other model parameters we have made a distinction between the random and the systematic part of those errors.

\subsubsection{Uncertainty in effective radius $\left(r_{\text {eff }}\right)$ and cloud optical thickness $(\tau)$}

The retrievals of MODIS Level 2 (the already processed raw spectral data) cloud optical and microphysical properties are described by Platnick et al. (2003). We used data from Collection 005, which are the first MODIS Cloud Optical Properties retrievals to include pixel-level uncertainty estimates (King et al., 2006). The mean error for both $r_{\text {eff }}$ and $\tau$ is about $13 \%$. Based on these references, we estimate a random component of $25 \%$, which, after spatially averaging the pixel values in the latitude-longitude box and temporally averaging these in bins, results in an error of $10 \%$. This error estimate acknowledges the systematic error in MODIS, but the temporal and spatial averaging levels out the random part of the error.

\subsubsection{Uncertainty in ratio between volume and effective radius $\left(k_{1}\right)$}

The parameter $k_{1}$ relates the volume radius to the $r_{\text {eff }}$ of a droplet size distribution and therefore contains information on the skewness and dispersion of the droplet size distribution. For the typical values of $N_{\mathrm{CD}}$ that we find in our study $\left(<100 \mathrm{~cm}^{-3}\right)$, the range of possible values of $k_{1}$ is relatively small. Following B06, we take $k_{1}=0.87 \pm 0.03$, so that $d k_{1} / k_{1}=0.03 / 0.87=3 \%$.

\subsubsection{Uncertainty in subadiabatic fraction $\left(F_{\mathbf{r}}\right)$}

The cloud model considers the fact that mixing in of air into the cloud is a non-adiabatic process by means of applying a subadiabatic fraction $F_{\mathrm{r}}$ to the cloud liquid water profile. For single-layered water clouds $F_{\mathrm{r}}$ will roughly vary between 0.3 and 0.9 , depending on the intensity of turbulent entrainment and vertical mixing of the clouds and surrounding air. A smaller $F_{\mathrm{r}}$, for fixed values of the other parameters, means that the liquid water is distributed over a larger vertical portion of the cloud, causing larger values of $h$ and smaller values of $N_{\mathrm{CD}}$. Since we have no further information on the actual $F_{\mathrm{r}}$, we applied a value of 0.6 for $F_{\mathrm{r}}$, comparable to the values used in previous studies (B06, Roebeling et al., 2008). For the uncertainty in $F_{\mathrm{r}}$, we follow B06 and set $F_{\mathrm{r}}$ to $0.6 \pm 0.3$. We numerically evaluated the cloud model for these variations in $F_{\mathrm{r}}$, which yielded an error of $26 \%$ for typical values of $r_{\mathrm{eff}}, \tau$ and $A_{\mathrm{ad}}$ found in our study.

\subsubsection{Uncertainty in adiabatic lapse rate of liquid water content mixing ratio $\left(A_{\text {ad }}\right)$}

The adiabatic lapse rate of liquid water mixing ratio $A_{\text {ad }}$ $\left(\mathrm{g} \mathrm{g}^{-1} \mathrm{~m}^{-1}\right)$ depends on temperature and pressure (Betts and Harshvardhan, 1987). Since it is equal to the amount of water that condenses when a parcel of air rises along the moist adiabat, it is coupled to the moist adiabatic lapse rate $\Gamma_{\mathrm{m}}$. To obtain the range in $A_{\text {ad }}$ during the season, we need information on the cloud base temperature and pressure. For Hyytiälä, the seasonal surface temperature range defined as the mean temperature in the warmest minus the mean temperature in the coldest month in the period of our retrievals is about $13{ }^{\circ} \mathrm{C}$ (e.g. Kulmala et al., 2004). By assuming a mean cloud base at $1000 \mathrm{~m}$ and a well-mixed boundary layer, the cloud base temperature $\left(T_{\mathrm{cb}}\right)$ can be estimated using:

$T_{\mathrm{cb}}=T_{\mathrm{s}}-h_{\mathrm{cb}} \Gamma_{\mathrm{d}}$

where:

$T_{\mathrm{s}}$ : surface temperature $(\mathrm{K})$

$h_{\mathrm{cb}}$ : cloud base height $(\mathrm{m})$

$\Gamma_{\mathrm{d}}$ : dry adiabatic lapse rate $\left(\mathrm{K} \mathrm{m}^{-1}\right)$

Under these assumptions, we arrive at an estimated minimum and maximum cloud base temperature over Hyytiälä of $-7^{\circ} \mathrm{C}$ and $6^{\circ} \mathrm{C}$, respectively. For an estimated mean cloud base pressure of $900 \mathrm{hPa}$, the corresponding minimum and maximum values of $A_{\mathrm{ad}}$ is $1.09 \times 10^{-8}$ and $1.78 \times 10^{-8}$, respectively. This yields a mean $A_{\text {ad }}$ of $1.44 \times 10^{-8} \pm$ $0.35 \times 10^{-8}$ implying an error of $24 \%$.

Variations in $A_{\text {ad }}$ are likely to be systematic on seasonal time scales, because of its coupling to temperature. Since a higher (lower) $A_{\text {ad }}$ leads to a higher (lower) $N_{\mathrm{CD}}$, this will lead to an overestimation of the $N_{\mathrm{CD}}$ in spring and autumn and an underestimation in summer.

\subsubsection{Uncertainty in other parameters}

Finally there are two parameters that control the vertical profiles of cloud optical properties in the cloud model, but which do not contribute significantly to the uncertainty in the calculations of $N_{\mathrm{CD}}$ and $h$, but which are discussed here for completeness.

The parameter $\alpha$ determines the curvature of the liquid water profile in the cloud model. Following B06, the value is fixed at 0.3 . They found that vertically averaged values of $N_{\mathrm{CD}}$ and $h$ are insensitive to the choice of $\alpha$.

Mixing with dry air from outside the cloud causes the liquid water path to deviate from the adiabatic water path. There are basically two contrasting possible assumptions on the effects of non-adiabaticity on the vertical profile of the liquid water path (1) either the departure from the adiabatic liquid water path is caused by a change in droplet volume, while cloud droplet number $N_{\mathrm{CD}}$ is constant, or (2) the $N_{\mathrm{CD}}$ is changed, while the droplet volume remains constant. The 


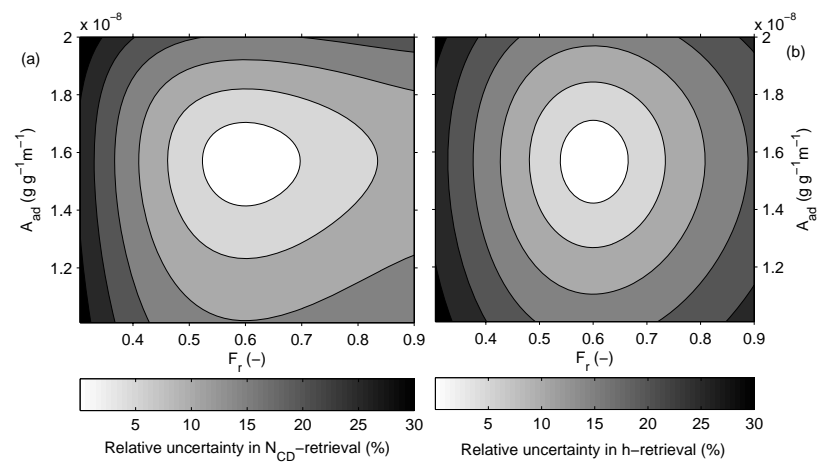

Fig. 2. Sensitivity analysis of the cloud model to subadiabatic fraction $F_{\mathrm{r}}$ and the adiabatic lapse ratio of liquid water content mixing ratio $A_{\text {ad }}$, which are the two major contributors to the total uncertainty in the retrievals of $N_{\mathrm{CD}}$ and $h$. The uncertainty is given in percent relative to the retrievals for the best guess of the respective parameters for (a) $N_{\mathrm{CD}}$ and (b) $h$. The calculations are performed with $r_{\text {eff }}=12$ and $\tau=9$.

former is referred to as homogeneous mixing, since the mixing evaporates water from all cloud droplets at an equal rate. The second situation is referred to as inhomogeneous mixing, because the cloud droplets are evaporated due to dilution of the cloud parcel with environmental air, while the volume of the remaining droplets is conserved. Interestingly, both assumptions result in about the same vertically averaged $N_{\mathrm{CD}}$ (B06), so our results are insensitive to the assumption on homogenous or inhomogeneous mixing conditions. We have chosen to use the inhomogeneous mixing assumption in our analysis.

Combining all the discussed uncertainties in the individual input parameters, using Eqs. (6) and (7), we obtain a relative error in the calculation of $N_{\mathrm{CD}}$ and $h$ of respectively $38 \%$ and $21 \%$. The most important parameters contributing to these errors are $F_{\mathrm{r}}$ and $A_{\mathrm{ad}}$. To illustrate the sensitivity of the cloud model to these two major sources of uncertainty on the error estimate, their combined effect is shown in Fig. 2.

These large errors mean that the $\mathrm{CCN}$ that reach cloud base only partly explain $N_{\mathrm{CD}}$ and $h$ as calculated by the model, due to variations in cloud microphysics and thermodynamics that are not constrained by the satellite data.

\section{Results}

We present an analysis of the seasonal cycle in $N_{\mathrm{CD}}$ and the relationship between $N_{\mathrm{CD}}$ and surface aerosol concentration and meteorology.

\subsection{Seasonal cycle in $N_{\text {CD }}$}

The seasonal cycles of satellite retrieved cloud properties from MODIS are shown in Fig. 3. The seasonal cycles in $r_{\text {eff }}$ and $\tau$ show both largest values at the beginning of April
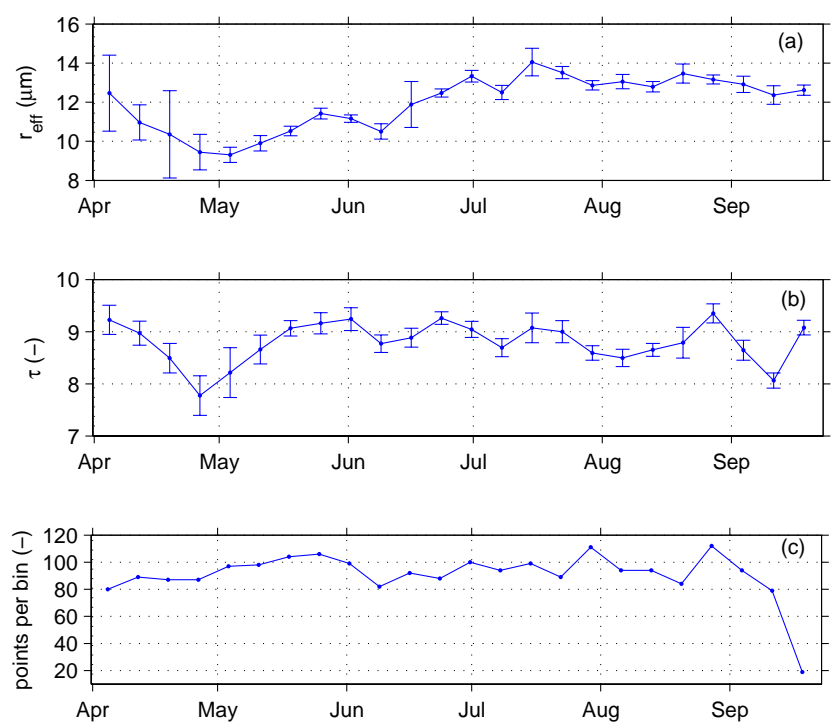

Fig. 3. Seasonal cycle in (a) MODIS effective radius $r_{\mathrm{eff}}$ and (b) cloud optical thickness $\tau$ over Hyytiälä for the years 2000 to 2008 (c) number of datapoints per bin. Each datapoint corresponds to one of 24 bins, each representing the median value of the variable over all years.

and a rapid decrease to a minimum in late April. After that both variables increase again. A large interannual variability results in large uncertainties in the retrievals of $r_{\text {eff }}$ in April. The cause of this large interannual variability for this period is not clear. The number of data points per bin and thus the occurrence of stratiform cloud cases does not show a clear seasonal variability (Fig. 3c), except for the last bin which has a significantly lower number of data points than the others.

We conducted a sensitivity analysis to assess the changes in retrieved variable values as a function of the spatial domain over which the cloud properties are averaged. Changing the size of the box to $1 \times 1^{\circ}$ and $3 \times 3^{\circ}$ did not significantly impact these outcomes. To test the sensitivity of the retrievals to the definition of the cloud type, we relaxed the $\tau$-constraint to include clouds with an optical thickness up to 100. This also did not change the seasonal cycle in observed cloud properties qualitatively.

The calculated seasonal cycle in $N_{\mathrm{CD}}$ mainly follows the variations in $r_{\text {eff }}$ (Fig. 4a). Seasonal variations in $\tau$ only slightly dampen the seasonal cycle in $N_{\mathrm{CD}}$. The real seasonal cycle in $N_{\mathrm{CD}}$ is expected to be less pronounced than depicted in Fig. 4, because of the dampening effect of the seasonal variation in $A_{\mathrm{ad}}$ on the $N_{\mathrm{CD}}$, due to its coupling to temperature as previously discussed in the section on error propagation. The range of absolute numbers of $N_{\mathrm{CD}}$ (between 40 and 100 per $\mathrm{cm}^{3}$ ) is rather low for continental areas and resemble the numbers found by B06 for a remote marine location. $N_{\mathrm{CD}}$ peaks in late April and early May. After experiencing 

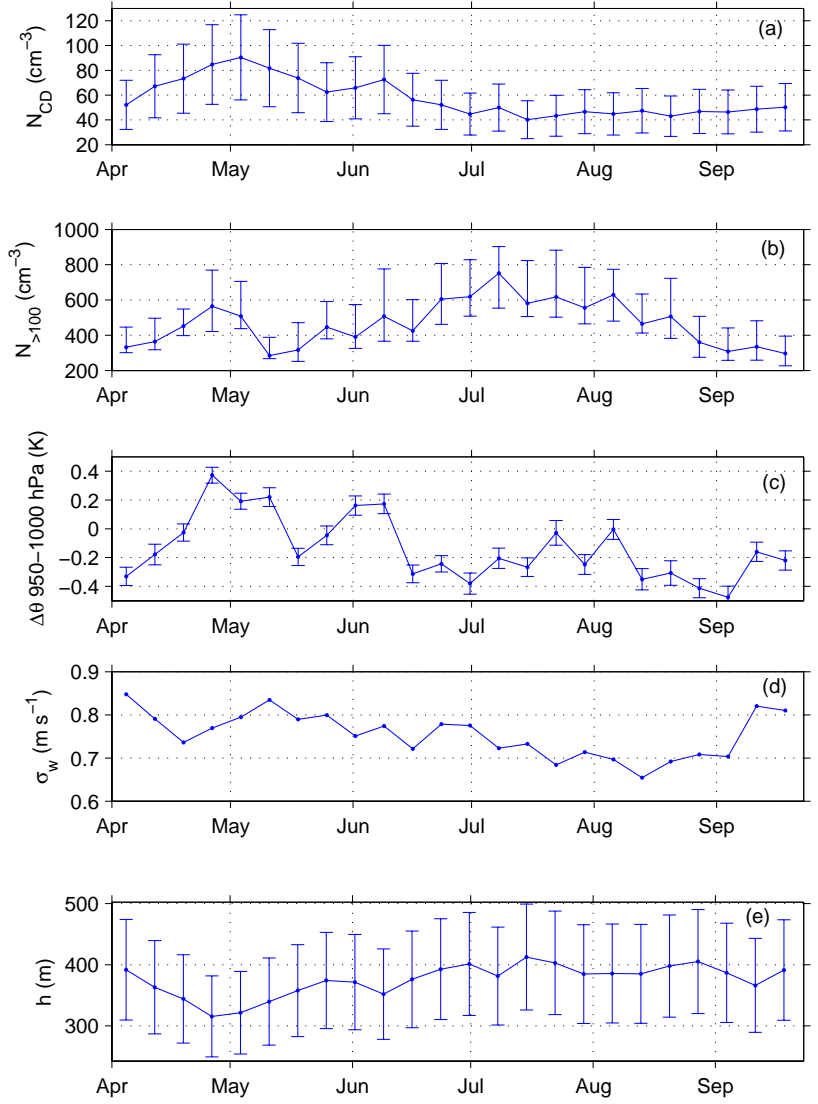

Fig. 4. Median seasonal cycle over 2000-2008 in (a) cloud droplet number concentration $N_{\mathrm{CD}}$, (b) surface observations of CCN-proxy concentrations $N_{>100}$, (c) potential temperature difference between the 1000 and $950 \mathrm{hPa}$-level $\Delta \theta_{1000-950}$, (d) standard deviation of the vertical wind speed $\sigma_{\mathrm{w}}$ and (e) cloud depth $h$. The errorbars in $N_{\mathrm{CD}}$ and $h$ indicate the uncertainty as calculated in Sect. 2.4. The errorbars in $N_{>100}$ indicate the concentrations of aerosols larger than $80 \mathrm{~nm}\left(N_{>80}\right.$, upper limit $)$ and larger than $120 \mathrm{~nm}\left(N_{>120}\right.$, lower limit), respectively, to account for the seasonal variation in critical diameter for $\mathrm{CCN}$-activity of aerosols at Hyytiälä (Sihto et al., 2010). Errorbars in $\Delta \theta_{1000-950}$ designate the standard error. Meaning of datapoints as in Fig. 3.

a minimum in mid-summer, $N_{\mathrm{CD}}$ seems to increase again in September, although this increase is not significant.

The calculations of cloud thickness $h$ follow the pattern of $r_{\text {eff }}$ and $\tau$, although the uncertainty of this result is large (Fig. 4d). This large uncertainty is a result of the uncertainty in several input parameters of the cloud model, that vary on seasonal time scales, a point which was also reported by B06. Roebeling et al. (2008), however, found good agreement between retrieved $h$ from the cloud model and $h$ as observed by ground based observations. A changing $h$ due to aerosol effects could in principle affect the cloud albedo, but this effect is not well understood and therefore we will not further discuss it.

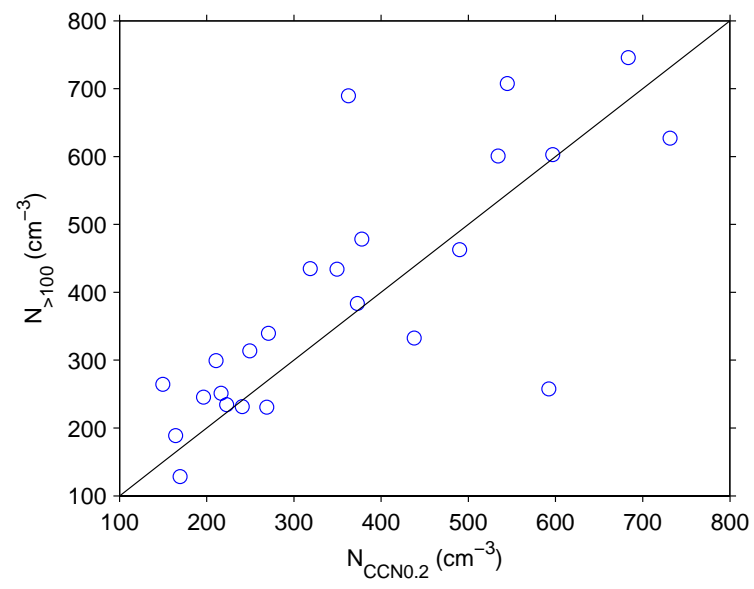

Fig. 5. Comparison of cloud condensation nuclei concentration at $0.2 \%$ supersaturation $N_{\mathrm{CCN} 0.2}$ and number concentration of aerosols with a diameter larger than $100 \mathrm{~nm} N_{>100}$ for the period July-September 2008 and April-June 2009. The line with a slope of 1 is included for visual guidance. Correlation coefficient $r=0.78$.

\subsection{Relation to surface aerosol concentrations and meteorology}

To find out if the seasonal cycle in $N_{\mathrm{CD}}$ is driven by the number of activated aerosols we compared it to surface concentrations of potential cloud nucleating aerosols. Since $\mathrm{CCN}$-measurements are not available for the whole period of available satellite observations, we applied observations of aerosols with a diameter above a certain cut-off diameter as a proxy for $\mathrm{CCN}$-concentrations $\left(N_{\mathrm{CCN}}\right)$ since size is in general a good indicator of ability of aerosols to act as $\mathrm{CCN}$ (Dusek et al., 2006). We find that the number concentration of aerosols with a diameter larger than $100 \mathrm{~nm}\left(N_{>100}\right.$ from here onwards) is the best proxy for $N_{\mathrm{CCN}}$ at $0.2 \%$ supersaturation (Fig. 5) with a correlation of $r=0.78$ for the period July-September 2008 and April-June 2009. The chosen supersaturation is similar to the supersaturation of $0.25 \%$ as used by B06 under weak convective conditions.

The seasonal cycle in $N_{\mathrm{CD}}$, however, does not resemble the seasonal cycle in $N_{>100}$ (Fig. 4). The latter does have a similar peak in spring as the former, but the maximum in summer in $N_{>100}$ cannot be seen in the $N_{\mathrm{CD}}$. Actually, comparing individual years, it turned out that the collective peak in spring is mainly reflecting a bias due to one year in which $N_{>100}$ had a very strong maximum in spring, which did not coincide with a maximum in $N_{\mathrm{CD}}$ for that year. The lack of correlation of $N_{\mathrm{CD}}$ and $N_{>100}$ can be seen from Fig. 6a. The correlation coefficient of the median seasonal cycles over all years in $N_{\mathrm{CD}}$ and $N_{>100}$ is $r=-0.24$, while for individual years it varies between $r=-0.36$ and $r=0.28$. In addition, the absolute numbers of $N_{\mathrm{CD}}$ and $N_{>100}$ differ approximately by one order of magnitude which further supports the lack of a strong coupling between surface aerosol concentration and low-altitude clouds. 

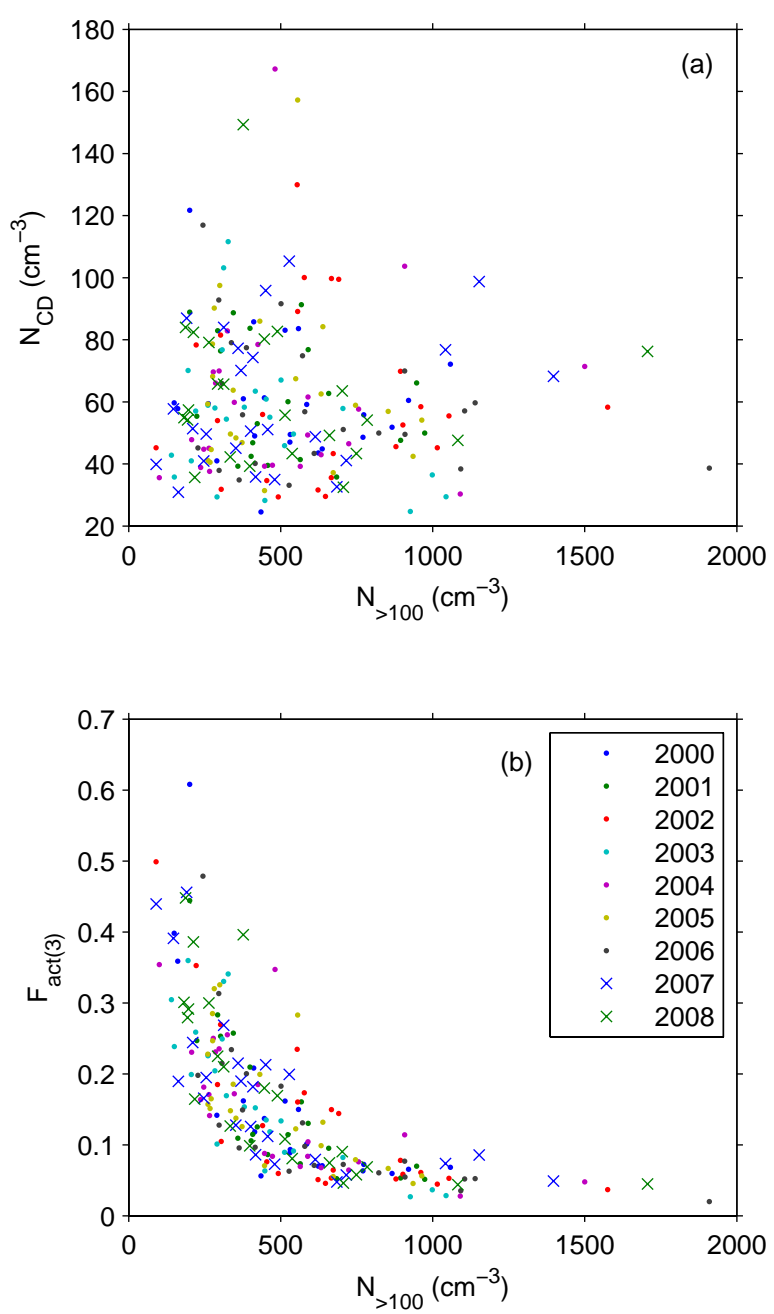

Fig. 6. (a) Comparison of CCN-proxy $N_{>100}$ and cloud droplet number concentration $N_{\mathrm{CD}}$ and (b) the activated fraction $F_{\text {act(3) }}$, defined as the ratio of $N_{\mathrm{CD}}$ and $N_{>100}$. Each data point represents the median of one bin, each bin representing a period of about one week over the years 2000 to 2008 . The different marker colors and styles indicate the different years, as shown in the legend.

Sihto et al. (2010), however, found that at Hyytiälä the critical aerosol diameter for cloud droplet activation $\left(d_{\text {crit }}\right)$ for a given supersaturation can vary considerably throughout the season, especially for low supersaturations. This may be caused by the seasonal variation in chemical composition of the aerosol at Hyytiälä: the aerosol contains a large fraction of organics in summer and has a relatively large contribution from anthropogenic sources in winter. It means that the seasonal dynamics of $N_{\mathrm{CCN}}$ may be different from those of $N_{>100}$.

For CCN at $0.2 \%$ supersaturation $d_{\text {crit }}$ varies roughly between 80 and $120 \mathrm{~nm}$ during the growing season (Sihto et al., 2010, Fig. 4). To test whether the lack of correlation with $N_{\mathrm{CD}}$ was a result of specifically using $N_{>100}$ as a proxy for low supersaturation $\mathrm{CCN}$, we also tested the seasonal cycle in aerosol concentrations for values of $d_{\text {crit }}$ of 80 and $120 \mathrm{~nm}$ ( $N_{>80}$ and $N_{>120}$, respectively). $N_{>80}$ and $N_{>120}$ are added to Fig. 4 as respectively the upper and lower bound of the errorbars around $N_{>100}$. The seasonal cycle of all these variables show the same two peaks in spring and summer, respectively, and therefore we conclude that the lack of correlation between $N_{\mathrm{CD}}$ and $N_{\mathrm{CCN}}$ does not strongly depend on the selection of the particular threshold diameter of the aerosol.

We discuss the activation of aerosols into cloud droplets in terms of the activated fraction $\left(F_{\text {act }}\right)$, here defined as:

$F_{\mathrm{act}}=\frac{N_{\mathrm{CD}}}{N_{\mathrm{CCN}}} \approx \frac{N_{\mathrm{CD}}}{N_{>100}}(-)$

where:

$N_{\mathrm{CD}}$ : cloud droplet number concentration $\left(\mathrm{cm}^{-3}\right)$

$N_{\mathrm{CCN}}$ : surface CCN-concentration $\left(\mathrm{cm}^{-3}\right)$

$N_{>100}$ : proxy for surface $N_{\mathrm{CCN}}$ at $0.2 \%$ supersaturation $\left(\mathrm{cm}^{-3}\right)$

$F_{\text {act }}$ thus gives information on the sensitivity of the cloud droplet activation to $N_{\mathrm{CCN}}$. This means that we do not distinguish between whether activation of cloud droplets is limited by the transport of $\mathrm{CCN}$ from the surface to cloud base or whether the actual activation of the $\mathrm{CCN}$ as cloud droplets is limiting. It is important to note that this definition of $F_{\text {act }}$ differs from others that are found in literature. In studies on cloud droplet activation, the activated fraction is defined as the ratio between the total aerosol concentration $\left(N_{\mathrm{A}}\right)$ at cloud base and $N_{\mathrm{CD}}$ (Kulmala et al., 1993; Reutter et al., 2009). Another definition is used in studies of CCNactivation (Jurányi et al., 2010; Sihto et al., 2010), where $F_{\text {act }}$ is defined as the ratio between $N_{\mathrm{A}}$ and $N_{\mathrm{CCN}}$ at the surface. These different definitions are illustrated in Fig. 7.

To illustrate the different activated fractions, we have calculated $F_{\text {act(1) }}$ and $F_{\text {act(3) }}$ for the period that we have data for $N_{\mathrm{A}}, N_{\mathrm{CCN}}$ and $N_{\mathrm{CD}}$, i.e. July to September 2008. Figure 8 shows that $N_{\mathrm{CCN}}$ increases with increasing $N_{\mathrm{A}} . F_{\text {act(1) }}$, which is the ratio of these, does not have a clear pattern over this period, but when looking at a longer period, Sihto et al. (2010) found a seasonal cycle in $F_{\text {act(1) }}$ at this site. The behaviour of $F_{\text {act(3) }}$ for this period is similar to that of the whole measurement period, showing little sensitivity of $N_{\mathrm{CD}}$ to $N_{\mathrm{CCN} 0.2}$. How $F_{\text {act(2) }}$ would behave, can be illustrated by the following limiting cases: (1) if $\mathrm{CCN}$-activation is transport limited, meaning that few $\mathrm{CCN}$ are transported from the surface to cloud base, we would expect a high $F_{\text {act(2) }}$, since few $\mathrm{CCN}$ reach cloud base, but those that do are activated. (2) If CCN-activation is limited by the activation itself, many $\mathrm{CCN}$ reach cloud base, but few are activated, resulting in a low $F_{\text {act(2) }}$. In reality, these 2 effects will be combined, but based on our results we cannot distinguish between them. In Fig. 6b we show that $F_{\text {act(3) }}$ is large for low $N_{>100}$ and small for high $N_{>100}$. This suggests that cloud droplet activation is not limited by the availability of cloud-nucleating aerosols; when $N_{>100}$ increases, droplet activation reaches saturation 


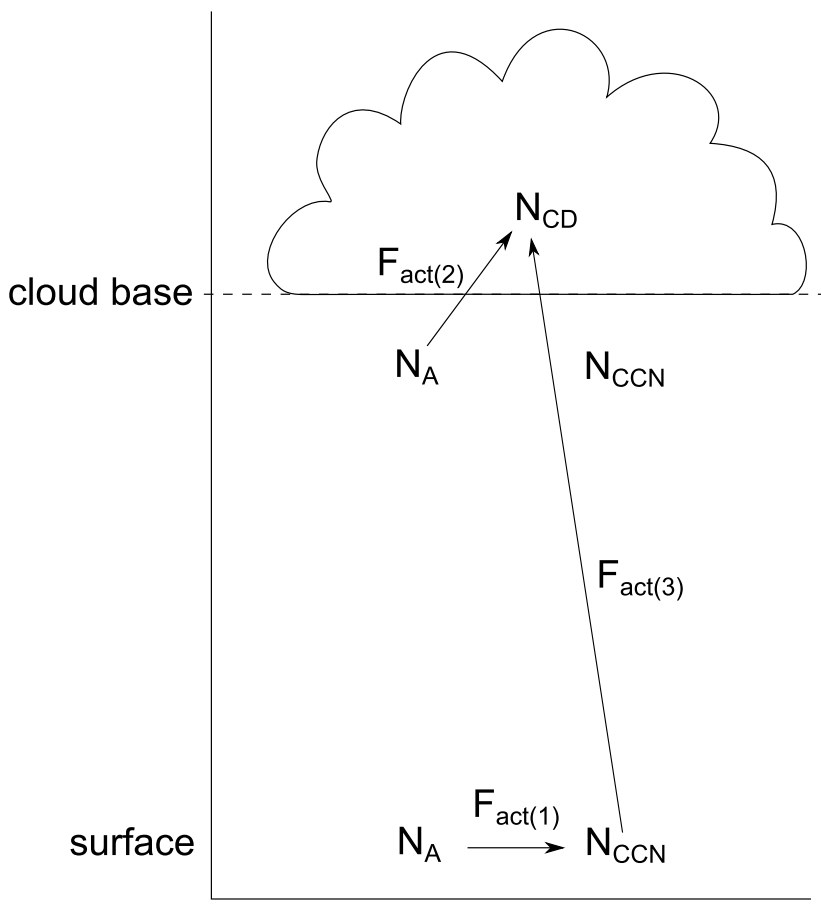

Fig. 7. Schematic illustration of the different definitions of activated fraction $\left(F_{\text {act }}\right)$ as found in literature: $F_{\text {act }}$ may refer to (1) the ratio of the ratio of the total aerosol concentration $\left(N_{\mathrm{A}}\right)$ and $\mathrm{CCN}$ concentration $\left(N_{\mathrm{CCN}}\right)$ at the surface (e.g. Jurányi et al., 2010; Sihto et al., 2010), to (2) the ratio of $N_{\mathrm{A}}$ at cloud base and $N_{\mathrm{CD}}$ (e.g. Kulmala et al., 1993; Reutter et al., 2009). In the present study, $F_{\text {act }}$ refers to (3) the ratio between $N_{\mathrm{CCN}}$ at the surface and $N_{\mathrm{CD}}$.

as can be seen from the decreasing $F_{\text {act(3) }}$. This situation is described as a regime where cloud droplet activation is updraft limited in a theoretical study of the influence of aerosol number, size and hygroscopicity on the cloud droplet activation of aerosols by Reutter et al. (2009) (see also Kulmala et al., 1993). When the updraft velocity is small, only a small fraction of the aerosols that reach cloud base activate as cloud droplets. Because these aerosols attract water, the supersaturation in the cloud is quenched, which inhibits further cloud droplet activation. Adding more aerosols will consequently not lead to more cloud droplets. The behavior of $F_{\text {act(3) }}$, as presented in Fig. $6 \mathrm{~b}$, is similar to their results for conditions of low updraft velocities and hence low supersaturations (Reutter et al., 2009, Fig. 4).

Information on the strength of convection could give more insight in the processes behind this behavior. As an indicator for convection, we use the potential temperature difference close to the surface, which represents thermal (in)stability in the sub-cloud layer. We obtained these data from the ECMWF ERA-Interim dataset on the ECMWF Data Server for the same spatial domain as we have obtained cloud properties for. Figure 4 shows a strong correlation between $N_{\mathrm{CD}}$ and the potential temperature difference between $1000-950 \mathrm{hPa}\left(\Delta \theta_{1000-950}\right)$ with a correlation
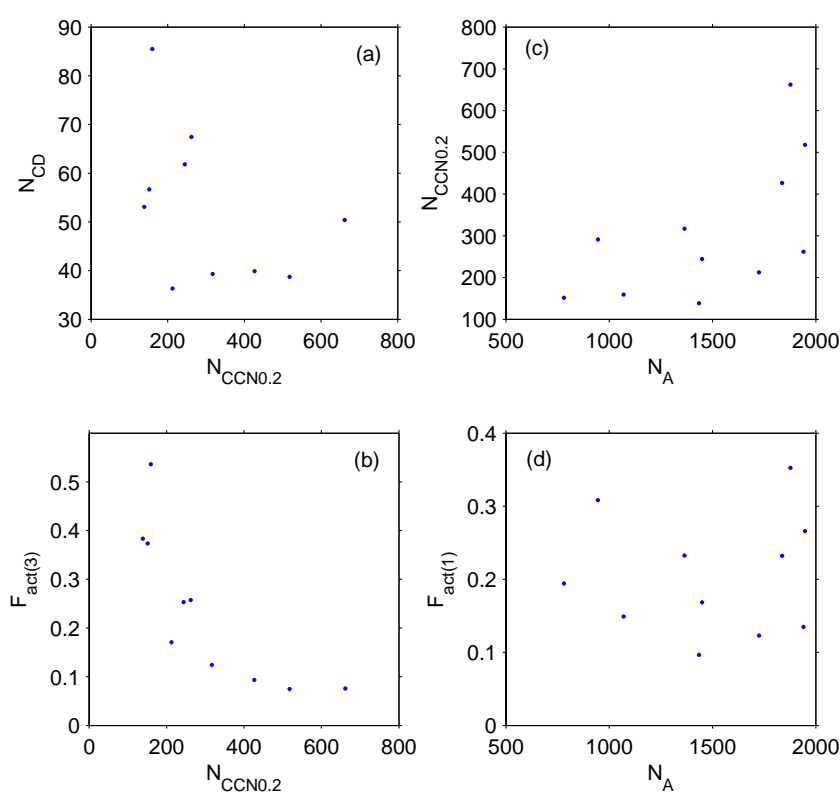

Fig. 8. The activated fraction Fact for the period JulySeptember 2008, for which there are data available of aerosol concentration $N_{\mathrm{A}}, \mathrm{CCN}$-concentration at $0.2 \%$ supersaturation $N_{\mathrm{CCN} 0.2}$ and cloud droplet concentration $N_{\mathrm{CD}}$. (a) Comparison of $N_{\mathrm{CCN} 0.2}$ and $N_{\mathrm{CD}}$, (b) $F_{\mathrm{act}(3)}$, defined as the ratio of $N_{\mathrm{CD}}$ and $N_{\mathrm{CCN} 0.2}$, (c) comparison of $N_{\mathrm{A}}$ and $N_{\mathrm{CCN} 0.2}$ and (d) $F_{\mathrm{act}(1)}$, defined as the ratio of $N_{\mathrm{CCN} 0.2}$ and $N_{\mathrm{A}}$.

coefficient $r=0.76$. The median seasonal cycle over all years in $N_{\mathrm{CD}}$ and $\Delta \theta_{1000-950}$ both show two peaks in spring and early summer, while the minimum in $N_{\mathrm{CD}}$ during summer is less pronounced in $\Delta \theta_{1000-950}$.

For the individual years, the correlations between $N_{\mathrm{CD}}$ and $\Delta \theta_{1000-950}$ are weaker and vary between 0.25 and 0.46 , but the sign is consistently positive. A similar, but somewhat weaker, relation was found between $N_{\mathrm{CD}}$ and the potential temperature difference between 1000-900 hPa.

We also looked at the relationship between updraft velocities and $N_{\mathrm{CD}}$. We use the standard deviation of the updraft velocity $\left(\sigma_{\mathrm{w}}\right)$ as measured at the SMEAR II station, since $\sigma_{\mathrm{w}}$ is a more reliable measure of vertical motions than the absolute values of the updrafts (Leaitch et al., 1996; Rosenfeld and Feingold, 2003). We found that the correlation between $\sigma_{\mathrm{w}}$ and $N_{\mathrm{CD}}$ is weak, but positive with $r=0.46$. This weak correlation could be caused by the fact that we compare point measurements with spatial averages and that we use measurements in the surface layer to discuss activation at cloud base.

\section{Discussion and conclusions}

Our results show that there is a clear seasonal cycle in $N_{\mathrm{CD}}$ in low level liquid water clouds over Hyytiälä. This seasonal 
cycle can, however, not be explained by seasonal variations in concentrations of cloud active aerosols. Rather, the sharp decrease of activated fraction with increasing $N_{\mathrm{CCN}}$ suggests that droplet activation in the clouds that are included in our analysis is updraft-limited (cf. Reutter et al., 2009). The good correlation between $N_{\mathrm{CD}}$ and the stability of the boundary layer, as diagnosed from the potential temperature difference, further indicates that the transport and mixing of the aerosols from the surface to cloud base is an important factor for determining which part of the aerosols actually activate into cloud droplets. Both findings could be explained by the fact that the studied clouds, low-level stratiform clouds over the boreal forest, represent a cloud type and environment, respectively, which are not associated with the occurrence of strong convection. However, based on this analysis, we cannot say whether the transport of aerosols from the surface to cloud base or the actual activation of those aerosols in the cloud is the limiting factor for cloud droplet activation (Fig. 7). Therefore, we use the term convective limitation to acknowledge that both the effects of transport and activation and possibly a combination of them could be limiting factors for cloud droplet activation.

We acknowledge, however, that the effects of the chemical composition of the aerosols that serve as $\mathrm{CCN}$ should be studied further to clarify its role in the seasonal cycle in $\mathrm{CCN}$-activation over the boreal forest. Especially under conditions of weak convection which results in low supersaturations the effect of the hygroscopicity could become important (e.g. Dusek et al., 2006). This effect is already clear from the uncertainty due to a seasonal variation in activation diameter as found by Sihto et al. (2010). This uncertainty is included as the error bars of Fig. $4 \mathrm{~b}$.

Formation of convective cumulus clouds, on the other hand, is closely coupled to surface conditions (e.g. Brown et al., 2002) and to conditions of stronger convection and therefore higher updraft velocities. Consequently, for these clouds the signal of the $N_{\mathrm{CD}}$ is more likely to follow the $N_{\mathrm{CCN}}$ at the surface. So our results, with a focus on stratiform clouds, do not rule out the possibility that aerosols from the boreal forest influence the other types of clouds over the forest. However, our results suggest that it is important to take the strength of convective transport into account when studying the AIE over boreal forests.

This convection-limitation may therefore be one of the factors to explain the weaker aerosol-cloud interaction as derived from satellite measurements of cloud properties combined with ground-based measurements of aerosol concentration, compared to ground-based measurements of both aerosols and cloud properties only as found by Lihavainen et al. (2010) for the northern high-latitude site Pallas. For the boundary layer clouds which are included in their satellite observations, the transport of aerosols to- and their activation in the cloud may be a limiting factor for their influence on cloud properties. This may be less important for the very low altitude clouds, which are that close to the surface that they surround the measurement station during some of the time.

Opposite to our results, Boers et al. (2006) found a clear relation between $N_{\mathrm{CD}}$ and $N_{\mathrm{CCN}}$. They, however, studied clouds over the ocean, which do not experience the strong diurnal cycle in atmospheric boundary layer as over land. Therefore a well-mixed boundary layer is almost constantly present, which facilitates the transport of aerosol particles from the ocean surface to cloud base. The low values of $N_{\mathrm{CD}}$ that they find may indicate an aerosol-limited regime of cloud droplet activation.

The method to retrieve $N_{\mathrm{CD}}$ that we applied in our study represents the state-of-the-art of current remote sensing techniques at high latitudes. Still, the error in the calculation of $N_{\mathrm{CD}}$ is large due to uncertainties in the representation of cloud microphysics and thermodynamics. This large error may cause $N_{\mathrm{CD}}$ to vary independently from the number of CCN that actually reach cloud base. In this case, we find that there is a seasonal cycle in $N_{\mathrm{CD}}$ that has a distinct shape that cannot be explained by a systematic seasonal variance in one of the input factors or cloud model parameters. Roebeling et al. (2008) showed that the method of B06 works well for carefully selected conditions (no drizzle, single layer, homogeneous in space and time, water phase), preferably supported with ground-based observations (lidar, radar, information about cloud base height and temperature). However, in their study over the Netherlands the number of cases that met the boundary conditions was limited. The same may be the case over Finland. Thus proving the first AIE from satellite retrievals requires very careful selection of representative cases. Therefore, we recommend that these satellite derived observations of $N_{\mathrm{CD}}$ should be validated with in-situ measurements of cloud properties over the boreal forest, for example by radiosonde or airplane measurements or by ground based remote sensing.

The data presented in this study are among the first observations of cloud properties over the boreal forest, related to the production of cloud active aerosols by the forest. We find that the $N_{\mathrm{CD}}$ in the studied clouds is insensitive to aerosol concentrations at the surface. Furthermore, information on the vertical structure of the atmosphere indicates that low $N_{\mathrm{CD}}$ is related to stable atmospheric conditions. From the combination of these two findings we conclude that convection may be a limiting factor for the activation of aerosols from the boreal forest as cloud droplets. Our analysis suggests that studies that do not take the role of convection into account when assessing the impact of aerosols from the boreal forest on cloud properties may overestimate their indirect radiative forcing. It stresses the need for a stronger involvement of the boundary layer and cloud research communities in such analysis of land-atmosphere interactions focusing on aerosols-cloud feedback mechanisms. 
Acknowledgements. The authors would like to thank Sanna-Liisa Sihto and Michael Boy for making the CCN-measurements available, Reinout Boers and Chiel van Heerwaarden for their help with the cloud model and two anonymous reviewers for their constructive comments. This research has received funding from ERC-Advanced Grant .ATMNUCLE. no. 227463, the Academy of Finland Center of Excellence program (project no. 1118615), and the ESRIN/Contract No. 4200023053/10/I-LG, STSE-ALANISAtmosphere-land Interactions Study Theme 3: Aerosols.

Edited by: B. Mayer

\section{References}

Aalto, P., Hämeri, K., Becker, E. D. O., Weber, R., Salm, J., Mäkelä, J. M., Hoell, C., O’Dowd, C. D., Karlsson, H., Hansson, H.-C., Väkevä, M., Koponen, I. K., Buzorius, G., and Kulmala, M.: Physical characterization of aerosol particles during nucleation events, Tellus B, 53, 344-358, 2001.

Albrecht, B. A.: Aerosols, Cloud Microphysics, and Fractional Cloudiness, Science, 245, 1227-1230, 1989.

Allan, J. D., Alfarra, M. R., Bower, K. N., Coe, H., Jayne, J. T., Worsnop, D. R., Aalto, P. P., Kulmala, M., Hyötyläinen, T., Cavalli, F., and Laaksonen, A.: Size and composition measurements of background aerosol and new particle growth in a Finnish forest during QUEST 2 using an Aerodyne Aerosol Mass Spectrometer, Atmos. Chem. Phys., 6, 315-327, doi:10.5194/acp-6-315-2006, 2006.

Andreae, M. O. and Rosenfeld, D.: Aerosol-cloud-precipitation interactions, Part 1. The nature and sources of cloud-active aerosols, Earth-Sci. Rev., 89, 13-41, 2008.

Bala, G., Caldeira, K., Wickett, M., Phillips, T. J., Lobell, D. B., Delire, C., and Mirin, A.: Combined climate and carbon-cycle effects of large-scale deforestation, Proc. Natl. Acad. Sci. USA, 104, 6550-6555, doi:10.1073/pnas.0608998104, 2007.

Bennartz, R.: Global assessment of marine boundary layer cloud droplet number concentration from satellite, J. Geophys. Res., 112, D02201, doi:10.1029/2006JD007547, 2007.

Bennartz, R., Watts, P., Meirink, J. F., and Roebeling, R.: Rainwater path in warm clouds derived from combined visible/nearinfrared and microwave satellite observations, J. Geophys. Res., 115, D19120, doi:10.1029/2009JD013679, 2010.

Betts, A. K. and Harshvardhan: Thermodynamic constraint on the cloud liquid water feedback in climate models, J. Geophys. Res., 92, 8483-8485, 1987.

Betts, R. A.: Offset of the potential carbon sink from boreal forestation by decreases in surface albedo, Nature, 408, 187-190, 2000.

Boers, R. and Rotstayn, L. D.: Possible links between cloud optical depth and effective radius in remote sensing observations, Q. J. Roy. Meteor. Soc., 127, 2367-2383, 2001.

Boers, R., Acarreta, J. R., and Gras, J. L.: Satellite monitoring of the first indirect aerosol effect: Retrieval of the droplet concentration of water clouds, J. Geophys. Res., 111, D22208, doi:10.1029/2005JD006838, 2006.

Brown, A. R., Cederwall, R. T., Chlond, A., Duynkerke, P. G., Golaz, J. C., Khairoutdinov, M., Lewellen, D. C., Lock, A. P., MacVean, M. K., Moeng, C. H., Neggers, R. A. J., Siebesma, A. P., and Stevens, B.: Large-eddy simulation of the diurnal cycle of shallow cumulus convection over land, Q. J. Roy. Meteor. Soc., 128, 1075-1093, 2002.

Carslaw, K. S., Boucher, O., Spracklen, D. V., Mann, G. W., Rae, J. G. L., Woodward, S., and Kulmala, M.: A review of natural aerosol interactions and feedbacks within the Earth system, Atmos. Chem. Phys., 10, 1701-1737, doi:10.5194/acp-10-17012010, 2010.

Cavalli, F., Facchini, M. C., Decesari, S., Emblico, L., Mircea, M., Jensen, N. R., and Fuzzi, S.: Size-segregated aerosol chemical composition at a boreal site in southern Finland, during the QUEST project, Atmos. Chem. Phys., 6, 993-1002, doi:10.5194/acp-6-993-2006, 2006.

Dal Maso, M., Sogacheva, L., Aalto, P. P., Riipinen, I., Komppula, M., Tunved, P., Korhonen, L., Suur-Uski, V., Hirsikko, A., Kurtén, T., Kerminen, V.-M., Lihavainen, H., Yrjö, V., Hansson, H.-C., and Kulmala, M.: Aerosol size distribution measurements at four Nordic field stations: identification, analysis and trajectory analysis of new particle formation bursts, Tellus B, 59, 350361, 2007.

Dal Maso, M., Hyvärinen, A., Komppula, M., Tunved, P., Kerminen, V.-M., Lihavainen, H., Viisanen, Y., Hansson, H.-C., and Kulmala, M.: Annual and interannual variation in boreal forest aerosol particle number and volume concentration and their connection to particle formation, Tellus B, 60, 495-508, 2008.

Dusek, U., Frank, G. P., Hildebrandt, L., Curtius, J., Schneider, J., Walter, S., Chand, D., Drewnick, F., Hings, S., Jung, D., Borrmann, S., and Andreae, M. O.: Size matters more than chemistry for cloud-nucleating ability of aerosol particles, Science, 312, 1375-1378, doi:10.1126/science.1125261, 2006.

Hakola, H., Tarvainen, V., Laurila, T., Hiltunen, V., Hellén, H., and Keronen, P.: Seasonal variation of VOC concentrations above a boreal coniferous forest, Atmos. Environ., 37, 1623-1634, 2003.

Hari, P. and Kulmala, M.: Station for Measuring EcosystemAtmosphere Relations (SMEAR II), Boreal Env. Res., 10, 315322, 2005.

Jurányi, Z., Gysel, M., Weingartner, E., DeCarlo, P. F., Kammermann, L., and Baltensperger, U.: Measured and modelled cloud condensation nuclei number concentration at the high alpine site Jungfraujoch, Atmos. Chem. Phys., 10, 7891-7906, doi:10.5194/acp-10-7891-2010, 2010.

Kavouras, I. G., Mihalopoulos, N., and Stephanou, E. G.: Formation of atmospheric particles from organic acids produced by forests, Nature, 395, 683-686, 1998.

Kerminen, V.-M., Lihavainen, H., Komppula, M., Viisanen, Y., and Kulmala, M.: Direct observational evidence linking atmospheric aerosol formation and cloud droplet activation, Geophys. Res. Lett., 32, L14803, doi:10.1029/2005GL023130, 2005.

King, M. D., Platnick, S. E., Hubanks, P. A., Arnold, G. T., Wind, G., and Wind, B.: Collection 005 change summary for the MODIS cloud optical property (06_OD) algorithm, in: Collection 005 Change Summary Documents, Level2MODISAtmosphere Products, version 3.1, 9 May 2006 NASA Goddard Space Flight Cent., Greenbelt, Md., available at: http:// modis-atmos.gsfc.nasa.gov/products_C005update.html (last access: 24 March 2010), 2006.

Komppula, M., Lihavainen, H., Kerminen, V.-M., Kulmala, M., and Viisanen, Y.: Measurements of cloud droplet activation of aerosol particles at a clean subarctic background site, J. Geophys. Res., 110, D06204, doi:10.1029/2004JD005200, 2005. 
Kulmala, M., Laaksonen, A., Korhonen, P., Vesala, T., Ahonen, T., and Barrett, J. C.: The effect of atmospheric nitric acid vapor on cloud condensation nucleus activation, J. Geophys. Res., 98, 22949-22958, 1993.

Kulmala, M., Hameri, K., Aalto, P. P., Makela, J. M., Pirjola, L., Nilsson, E. D., Buzorius, G., Rannik, U., Maso, M. D., Seidl, W., Hoffman, T., Janson, R., Hansson, H. C., Viisanen, Y., Laaksonen, A., and O'Dowd, C. D.: Overview of the international project on biogenic aerosol formation in the boreal forest (BIOFOR), Tellus B, 53, 324-343, doi:10.1034/j.16000889.2001.530402.x, 2001.

Kulmala, M., Suni, T., Lehtinen, K. E. J., Dal Maso, M., Boy, M., Reissell, A., Rannik, Ü., Aalto, P., Keronen, P., Hakola, H., Bäck, J., Hoffmann, T., Vesala, T., and Hari, P.: A new feedback mechanism linking forests, aerosols, and climate, Atmos. Chem. Phys., 4, 557-562, doi:10.5194/acp-4-557-2004, 2004.

Kurtén, T., Kulmala, M., Dal Maso, M., Suni, T., Reissell, A., Vehkamäki, H., Hari, P., Laaksonen, A., Viisanen, Y., and Vesala, T.: Estimation of different forest-related contributions to the radiative balance using observations in southern Finland, Boreal Env. Res., 8, 275-285, 2003.

Laaksonen, A., Kulmala, M., O’Dowd, C. D., Joutsensaari, J., Vaattovaara, P., Mikkonen, S., Lehtinen, K. E. J., Sogacheva, L., Dal Maso, M., Aalto, P., Petäjä, T., Sogachev, A., Yoon, Y. J., Lihavainen, H., Nilsson, D., Facchini, M. C., Cavalli, F., Fuzzi, S., Hoffmann, T., Arnold, F., Hanke, M., Sellegri, K., Umann, B., Junkermann, W., Coe, H., Allan, J. D., Alfarra, M. R., Worsnop, D. R., Riekkola, M. -L., Hyötyläinen, T., and Viisanen, Y.: The role of VOC oxidation products in continental new particle formation, Atmos. Chem. Phys., 8, 2657-2665, doi:10.5194/acp-82657-2008, 2008.

Lappalainen, H. K., Sevanto, S., Bck, J., Ruuskanen, T. M., Kolari, P., Taipale, R., Rinne, J., Kulmala, M., and Hari, P.: Day-time concentrations of biogenic volatile organic compounds in a boreal forest canopy and their relation to environmental and biological factors, Atmos. Chem. Phys., 9, 5447-5459, doi:10.5194/acp-9-5447-2009, 2009.

Leaitch, W. R., Banic, C. M., Isaac, G. A., Couture, M. D., Liu, P. S. K., Gultepe, I., Li, S. M., Kleinman, L., Daum, P. H., and MacPherson, J. I.: Physical and chemical observations in marine stratus during the 1993 North Atlantic Regional Experiment: Factors controlling cloud droplet number concentrations, J. Geophys. Res., 101, 29123-29135, doi:10.1029/96jd01228, 1996

Lihavainen, H., Kerminen, V. M., Komppula, M., Hatakka, J., Aaltonen, V., Kulmala, M., and Viisanen, Y.: Production of "potential" cloud condensation nuclei associated with atmospheric new-particle formation in northern Finland, J. Geophys. Res., 108, 4782, doi:10.1029/2003JD003887, 2003.

Lihavainen, H., Kerminen, V.-M., Komppula, M., Hyvärinen, A.-P., Laakia, J., Saarikoski, S., Makkonen, U., Kivekäs, N., Hillamo, R., Kulmala, M., and Viisanen, Y.: Measurements of the relation between aerosol properties and microphysics and chemistry of low level liquid water clouds in Northern Finland, Atmos. Chem. Phys., 8, 6925-6938, doi:10.5194/acp-8-6925-2008, 2008.

Lihavainen, H., Kerminen, V.-M., and Remer, L. A.: Aerosol-cloud interaction determined by both in situ and satellite data over a northern high-latitude site, Atmos. Chem. Phys., 10, 1098710995, doi:10.5194/acp-10-10987-2010, 2010.

Lohmann, U. and Feichter, J.: Global indirect aerosol effects: a re- view, Atmos. Chem. Phys., 5, 715-737, doi:10.5194/acp-5-7152005, 2005.

McFiggans, G., Artaxo, P., Baltensperger, U., Coe, H., Facchini, M. C., Feingold, G., Fuzzi, S., Gysel, M., Laaksonen, A., Lohmann, U., Mentel, T. F., Murphy, D. M., O’Dowd, C. D., Snider, J. R., and Weingartner, E.: The effect of physical and chemical aerosol properties on warm cloud droplet activation, Atmos. Chem. Phys., 6, 2593-2649, doi:10.5194/acp-6-2593-2006, 2006.

Nakajima, T., Higurashi, A., Kawamoto, K., and Penner, J. E.: A possible correlation between satellite-derived cloud and aerosol microphysical parameters, Geophys. Res. Lett., 28, 1171-1174, 2001.

O’Dowd, C. D., Aalto, P., Hmeri, K., Kulmala, M., and Hoffmann, T.: Aerosol formation: Atmospheric particles from organic vapours, Nature, 416, 497-498, 2002.

O’Dowd, C. D., Yoon, Y. J., Junkermann, W., Aalto, P., Kulmala, M., Lihavainen, H., and Viisanen, Y.: Airborne measurements of nucleation mode particles II: boreal forest nucleation events, Atmos. Chem. Phys., 9, 937-944, doi:10.5194/acp-9-937-2009, 2009.

Platnick, S. and Twomey, S.: Determining the susceptibility of cloud albedo to changes in droplet concentration with the Advanced Very High Resolution Radiometer, J. Appl. Meteorol., 33, 334-347, 1994.

Platnick, S., King, M. D., Ackerman, S. A., Menzel, W. P., Baum, B. A., Riedi, J. C., and Frey, R. A.: The MODIS cloud products: Algorithms and examples from Terra, IEEE T. Geosci. Remote., 41, 459-473, 2003.

Reutter, P., Su, H., Trentmann, J., Simmel, M., Rose, D., Gunthe, S. S., Wernli, H., Andreae, M. O., and Pschl, U.: Aerosoland updraft-limited regimes of cloud droplet formation: influence of particle number, size and hygroscopicity on the activation of cloud condensation nuclei (CCN), Atmos. Chem. Phys. 9, 7067-7080, doi:10.5194/acp-9-7067-2009, 2009.

Roebeling, R. A., Placidi, S., Donovan, D. P., Russchenberg, H. W. J., and Feijt, A. J.: Validation of liquid cloud property retrievals from SEVIRI using ground-based observations, Geophys. Res. Lett., 35, L05814, doi:10.1029/2007GL032115, 2008.

Rosenfeld, D. and Feingold, G.: Explanation of the discrepancies among satellite observations of the aerosol indirect effects, Geophys. Res. Lett., 30, 1776, doi:10.1029/2003GL017684, 2003.

Sihto, S.-L., Mikkilä, J., Vanhanen, J., Ehn, M., Liao, L., Lehtipalo, K., Aalto, P. P., Duplissy, J., Petäjä, T., Kerminen, V.-M., Boy, M., and Kulmala, M.: Seasonal variation of $\mathrm{CCN}$ concentrations and aerosol activation properties in boreal forest, Atmos. Chem. Phys. Discuss., 10, 28231-28272, doi:10.5194/acpd-10-282312010, 2010.

Sogacheva, L., Saukkonen, L., Nilsson, E. D., Maso, M. D., Schultz, D. M., Leeuw, G. D., and Kulmala, M.: New aerosol particle formation in different synoptic situations at Hyytiälä, Southern Finland, Tellus B, 60, 485-494, 2008.

Spracklen, D. V., Bonn, B., and Carslaw, K. S.: Boreal forests, aerosols and the impacts on clouds and climate, Phil. Trans. R. Soc. A, 366, 4613-4626, 2008.

Szczodrak, M., Austin, P. H., and Krummel, P. B.: Variability of optical depth and effective radius in marine stratocumulus clouds, J. Atmos. Sci., 58, 2912-2926, doi:10.1175/15200469(2001)058<2912:VOODAE > 2.0.CO;2, 2001. 
Tunved, P., Hansson, H. C., Kerminen, V. M., Strom, J., Maso, M. D., Lihavainen, H., Viisanen, Y., Aalto, P. P., Komppula, M., and Kulmala, M.: High natural aerosol loading over boreal forests, Science, 312, 261-263, doi:10.1126/science.1123052, 2006.

Tunved, P., Ström, J., Kulmala, M., Kerminen, V. M., Maso, M. D., Svenningson, B., Lunder, C., and Hansson, H. C.: The natural aerosol over Northern Europe and its relation to anthropogenic emissions: implications of important climate feedbacks, Tellus B, 60, 473-484, 2008.
Twomey, S.: The influence of pollution on the shortwave albedo of clouds, J. Atmos. Sci., 34, 1149-1152, doi:10.1175/15200469(1977)034<1149:TIOPOT>2.0.CO;2, 1977.

Várnai, T. and Marshak, A.: View angle dependence of cloud optical thicknesses retrieved by Moderate Resolution Imaging Spectroradiometer (MODIS), J. Geophys. Res., 112, D06203, doi:10.1029/2005JD006912, 2007. 